\title{
The Local Wisdom of Batak Toba through the Philosophy of Dalihan Na Tolu in a Kinship Environment
}

\author{
Rufer Firma Harianja ${ }^{1}$, Ajat Sudrajat ${ }^{2}$ \\ ${ }^{1,2}$ Postgraduate Program in History Education Department, Universitas Negeri Yogyakarta, Indonesia \\ Ruperfirma@gmail.com
}

\begin{abstract}
Local wisdom is a wisdom of noble values that is still wise and relies on a philosophy of behavior and ethics. Batak Toba has a wisdom that regulates the system and life patterns of others, known as Dalihan $\mathrm{Na}$ Tolu. This paper discusses how the Dalihan Na Tolu philosophy affects the kinship system in the Batak Toba community and its benefits for the wider community. To interpret the data, this paper uses a qualitative method with a content analysis approach to analyze in depth what is in a discussion in the text, which can be grouped according to the theme or material to be studied. Dalihan Na Tolu is connected from the old belief of the Batak Toba tribe to Mula Jadi Na Bolon (God of the universe) who also rules the three realms, namely the heavens, the earth and after death. Dalihan Na Tolu has a philosophy, namely somba marhula-hula, manat mardongan tubu, and elek marboru". It means that every Batak person must respect / obey his wife's family, be careful with family members and be obedient to his husband's side. The cultural system of dalih na tolu is required to behave helping or caring for relatives at every opportunity and this behavior for the Toba Batak people is perceived as a high value and is also a noble and noble act. In fact, the Dalihan Natolu philosophy is not only for the Batak people, because fair, social and religious values are the needs of every human being.
\end{abstract}

Keywords

Dalihan Na Tolu; kinship system; Batak Toba

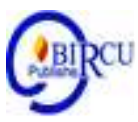

\section{Introduction}

In the last decade or so local wisdom is very much to be discussed. Local wisdom is like a panacea to answer the challenges or complexity of problems faced by modern humans due to irrational behavior in conquering nature. The failure of modern humans to manage the problems they face forces them to look for alternative options. Modern humans tend to get deadlocked and frustrated, so they look for cultural values that have long been abandoned and damaged by human behavior itself. Local wisdom is wisdom and noble values contained in the richness of local culture.

With varying meanings local wisdom is often associated with local communities. Local wisdom is a good value local (local) ideas which are followed by community members with full wisdom and wisdom (Sartini, 2004: 111). The real thing that is close to the direct life of students, one of which lies in the culture of local wisdom that surrounds student life (Frince, 2020). Meanwhile, according to Zulkarnain and Febriamansyah, local wisdom is in the form of certain principles and methods that are adhered to, understood, and applied by local communities in interacting and interacting with their environment and transformed into a system of values and customary norms (Zulkarnain, 2008: 69). . Local wisdom is a behavior 
that has been practiced from generation to generation to meet the needs and challenges of life in society through traditional views and knowledge (Cecep, 2011: 68).

The system for fulfilling their needs must cover all elements of life, religion, science, economics, technology, social organization, language and communication, and the arts. In addition, the policies of local wisdom rely on traditionally institutionalized philosophies, values, ethics and behaviors which include natural, human and cultural resources in a sustainable manner (Abubakar, 2010: 172). It can be concluded that local wisdom is a wisdom of noble values that has values, is wise and relies on a philosophy of behavior and ethics. Local wisdom is reflected in the philosophy or way of life of humans who think about and use it.

Indonesia is a country that is rich in culture and has many ethnicities / tribes. According to data from BPS, there are 1331 ethnic categories in Indonesia. Batak Toba is one of the tribes and forms of diversity (Nainggolan, 2012: 4). The Toba Batak is one of the six sub-ethnic Batak from other tribes, namely, the Karo Batak, Simalungun, Angkola, Mandailing, Pakpak Dairi, and Nias which is interesting to mention. Toba Batak culture is famous for its philosophy, namely the Dalihan $\mathrm{Na}$ Tolu or three stoves which regulates the kinship system and is a determining factor in Batak cultural customs. The actualization of its values is evident in the implementation of adat. For example, in the custom of marriage, death, entering a new house, and so on. Literally Dalihan Natolu is the three furnaces that support the Toba Batak human life in this world (Adrian 2018: 348). The philosophy of the Batak people is an essential truth that describes the characteristics of the Batak, which regulates the behavior of kinship and interactions between one another, influencing one another, mutually determining, interconnecting, needing each other which is tied in a custombased concept, namely the Dalihan Na system tolu (Patik 2002: 144).

The kinship system referred to in social order is a pattern of behavior based on experience and appreciation which is integrated in an ideal and physical form of culture (1992: 60). Cultural values and rules are a reality which is the handle that is needed in daily life by the community, among others, regarding the relationship between children and fathers, children and mothers, and so on to the relationship between individuals and individuals and groups, both small groups and large groups. . The kinship system has an important meaning in many societies, both simple and advanced societies, relationships with ancestors and relatives are the key to relationships in social structures. Relationships with these relatives become the axis of various interactions, obligations, loyalties,

In a society where kinship loyalty is very important to relatives in place of loyalty to others. This means that the kinship system is closely related to the social structure it builds further. The kinship system determines a person's position in society, namely the position of men and the position of women (Meiyenti 2012: 57). Therefore, the author is interested in digging deeper into the local wisdom of the Dalihan $\mathrm{Na}$ Tolu philosophy, especially in the kinship system which is of course very beneficial for the wider community.

\section{Research Methods}

The method used is a qualitative method with literature studies by looking at phenomology which aims to compare and unify the results of research conducted with the findings from previous literature and to determine the various similarities and differences in the various findings obtained from new research. just done (Burn \& Grove 1993). In addition, a content analysis approach is needed to explore subjective interpretations of text content through a systematic classification process of coding and identifying themes or patterns 
(Hsiehn \& Shannon, 2005: 1278). Mayring (2000: 2) argues that content analysis is an empirical, methodological approach to analysis that is controlled by texts in the context of their communication, following the content analytic rules and step-by-step models. without quantification of the rash. So it can be explained that Content Analysis is a way to analyze in depth what is in a discussion in the text, which can be grouped according to the theme or material to be studied.

\section{Discussion}

\subsection{The history of the Toba Batak}

There are several questions and opinions on this matter. For example, did the name appear after the arrival of the migrant group in the land of Batak or at first there was a group where they already had a tribal name called "Batak" from their origin, or the name "Batak" itself after the appearance of Siraja Batak. There is also an opinion that the term Batak comes from the word "bataha", which is the name of a country in Burma. Based on this information the Batak people then moved towards the archipelago. The word "bataha" then changed to the word "batak". According to Batak mythology, the origin of the Batak tribe comes from the Batak land, precisely from Pusuk Buhit, a mountain located on the western edge of Samosir Island (Gultom, 2010: 34).

This island is in the middle of Lake Toba which is now famous as a tourist destination. Administratively, this area is included in North Sumatra. The Batak area was made into a district, namely North Tapanuli Regency, the capital of which is Tarutung. In this myth, it is stated that the first humans were Siraja Ihat Manisia and Siboru Ihat Manisia. From their marriage, three children were born, namely Raja Miokmiok, Patundal Nibegu and Aji Lapaslapas. King Miokmiok had one son, Eng Banua. Furthermore, Eng Banua had three sons, namely the King of Aceh, the King of Bonang-bonang and the King of Jau. Raja Bonang-bonang has an only child named Guru Tantan Debata. The Tantan Debata teacher with the title Umpu Raja Ijolma has an only son named Siraja Batak,

According to historical studies, Siraja Batak is the ancestor of the Batak people. He is the foundation stone of the beginning of the history of the Batak tribe.One of them is language and writing or script (Batak letters). The descendants of Siraja Batak then developed more and more through the path of their two children, Tatea Bulan and Isumbaon. In the fifth and sixth generations after Siraja Batak, there were several clans that are now known to have been dozens of clans (Gultom, 2010: 67).

\subsection{Dalihan Na Tolu's Cultural Values and Philosophy}

One of the Toba Batak cultural values which he is proud of in his system of social and kinship is manifested in very thick kinship based on blood lineage (genalogical) and marriage which has been passed down from generation to generation until now known as the philosophy of "Dalihan $\mathrm{Na}$ Tolu". In the Batak cultural system, "dalih na tolu" or known as "tungku nan three", which describes a three-row stove, three twirl threads, a three-legged umbrella, etc. functions as a guideline that regulates, controls and gives direction to behavior ( the behavior) and actions (attitudes or patterns of action) of the Toba Batak people will of course have different meanings and meanings from other cultural values that exist in Sumatra. Dalihan natolu gamabar from a stove which is supported by three stone pillars. The three stone pillars were driven into the ground and arranged so that the stones were evenly spaced and close to each other. In order for the load on which it does not tilt or shift, the rock face 
must be the same height as the ground level. It is said that the ancient people, including the Batak people, used such stoves to cook in the kitchen.

The Toba Batak people are familiar with the symbol of the number three and "trinity" which is very thick in their daily life. Numbers have their own meaning, are rich and contain mythic-religious elements. The numbers used are odd numbers, especially three (Sihombing, 2000: 96). As with the concept of macrocosmic totality, the Batak Toba Tua people believe that Debata Mulajadi Na Bolon (God of the universe) controls all banua which means all of nature, both banua ginjang which means above the sky, banua tonga or in the world or banua toru or in the grave. In the concept of totality, the Toba Tua Batak people also believe in the variety of ni Debata (three kinds of debata or God), namely Batara Guru, Sori Pada and Mangala Bulan. They are called debata na tolu (three debata) or debata sitolu sada (triune God, three but one). Regarding the presence of these three debates, there are two opinions. The first opinion as expressed by $\mathrm{AB}$ Sinaga said that the debata na tolu namely Batara Guru, Sori Pada and Mangala Bulan was created by Debata Mulajadi Na Bolon (Sinaga 1981: 68). The second opinion as expressed by the PHO. Lumban Tobing said that debata na tolu is itself from Debata Mulajadi Na Bolon. Debata Mulajadi Na Bolon transformed into three selves, namely as debata banua ginjang, as debata banua tonga and as debata banua toru. As a banua ginjang debata he is called Debata Batara Guru or Tuan / Ompu Bubi Na-Bolon, as a banua tonga debata he is called Debata Soripada or Tuan / Ompu Silaon Na Bolon, and as a banua toru debata he was called Debata Mangala Bulan or Tuan / Ompu Pane Na Bolon (Tobing 1963: 27). Therefore, the traditional Batak Toba people believe in sada Debata in ginjang, sada Debata in tonga, Sada Debata ditoru (one god above, one god in the middle and one god below).

Odd numbers symbolize life and are often associated with things that are transcendent and mystical. Odd numbers are considered as numbers that have supernatural powers. While even symbolizes disease, suffering and death (Sinaga, 1991: 8). The number three has a very special meaning for the Toba Batak people. These numbers influence the life and way of thinking of the Toba Batak people. This can be seen in the cosmology and philosophy of his life (Sihombing, 2018: 356).

Therefore, diversion na tolu is a motivation to behave through the values contained therein and used as a life order. The Toba Batak people live up to dalih na tolu as a system of cultural values that provides guidance for orientation, perception, and definition of reality or reality (Harahap, 1987: 78). These numbers influence the life and way of thinking of the Toba Batak people. This can be seen in the cosmology and philosophy of his life.

Literally Dalihan Natoluis the three mast furnace. The word dalih comes from the word dalik which means dais (touching). The three stoves are symbols of Hula-hula, Dongan Sabutuha and Boru. Meanwhile, the Toba community is a symbol of a pot that is placed on top of the dalih (Marbun and Hutapea, 1987: 37). The Toba Batak people believe that the universe was created by Mulajadi Na Bolon (The Great Origin). The belief in Debata Natolu (three Gods) inspires, colors, and inspires all the traditional activities - culture and actions of the Toba Batak people, both individually and collectively.

This is expressed in his life philosophy which is called Dalihan Natolu. The teachings are "somba marhula-hula, manat mardongan tubu, and elek marboru". It means that every Batak person must respect / obey his wife's family, have a cautious attitude towards his siblings in the same family so that there are no disputes, and have affection for his boru. Hula-hula is a representation of Debata Bataraguru as a source of supernatural strength, a source of life, a source of blessings, happiness and a place to ask for advice. Therefore, in everyday life, when there is heavy grief, and unspeakable hardships, for example, not having 
children, he will go to his hula-men to "worship" and ask for blessings so that his suffering will end (Sihombing, 1997: 77). This is confirmed by the phrase: "molo naeng ho gabe,

According to Gultom Raja Marpodang the position of Hula-hula was so noble and honorable. Related to this, it appears in the proverb which reads "Hula-hula i do debata na tarida"It means that Hula-hula is the visible debate. His blessings and prayers have a true effect on livelihoods. As for what is called Hula-hula is the group or party that gives the wife.

The second forming element Dalihan Natolu besides Hula-hula is Dongan Sabutuha / tubu. It literally means siblings, from one mother, one blood. The Dongan Sabutuha group is considered close relatives because they still come from one ancestor and one clan even though they don't know each other, especially for the generations below them. Dongan Sabutuha is a representation of the presence of Debata Soripada, the emanation of Mulajadi $\mathrm{Na}$ Bolon's power in terms of holiness. The purity of Mulajadi $\mathrm{Na}$ bolon is symbolized by the white color, must be guarded so that it is not dirty. In Toba Batak society, this color is a symbol of equality and equality. The symbol is applied to Dongan Sabutuha because they have the same position, rights and obligations in the customs, because of that the relationship is very fluid, natural, close, open, free for mutual correction. There is an awareness that groups of one clan / person of the same clan are very vulnerable to conflict (Simanjuntak, 2002: 201). This happens because they are close relatives, often meet, relate, interact in everyday life. If you are not careful and prudent, it is very possible for conflict or division to occur among your fellow clans. Because of that the ancestors taught "manat mardongan sabutuha / tubu" (must be careful with relatives of the same family).

The third element that forms philosophy Dalihan Natoluis Boru. Boru are the group or party to receive the wife and also all the brothers from Boru, the kin group from Boru, the same clan brothers from Boru are called the Boru group or party. Boru's position is as parhobas (servants) in every Hula-hula activity. Boru is a representation of God through His third servant, Mangalabulan, as a symbol of the presence of God's "power" in the world. Boru is the backbone in every traditional ceremony.

Group Boruwilling to give and do anything for his hula-hula because hula-hula is the source of his own life. Just as Mangalabulan has the power to continue or hinder the blessings of God so does Boru. Although Bataraguru blessed the hula hula request to give offspring to Boru, if Boru did not respect his hula-hula, it would not be achieved. On the other hand, the honor given to Hula-hula Boru will bring abundant blessings from Bataraguru, both for Boru himself and for the hula-hula party (Tobing, 1960: 96).

Here is displayed a deep relationship that is beautiful, perfect, enchanting, indissoluble. Its beauty emanates from the third harmonite of the debata (Bataraguru, Soripada, Mangalabulan) which support each other. The third value teaching of the Toba Batak ancestors is "elek marboru". It was explained above that Boru must respect Hula-hula, on the other hand Hula-hula must be persuasive, nurture, pay attention, and praise Boru. This attitude will be evident in traditional ceremonies. Hula-hula will give awards in the form of jambar dengke (fish) or jambar juhut, as well as boras si pir ni tondi (rice as a symbol of blessing). This gift is a sign of recognition and appreciation for his presence and status as boru. Hula-hula must love her Boru, and Boru must respect her Hula-hula and be willing to sacrifice to fulfill Hula-hula's request.

Based on this advice, the Toba Batak people in the dalih na tolu cultural system are required to behave helping or caring for their relatives at every opportunity and this behavior for the Toba Batak people is perceived as high value and is also a noble and noble act (Armawy, 2008: 160). 


\subsection{Benefits for the Wider Community and the Present Generation}

The true philosophy Dalihan Natolunot only for the Batak people, because fair, social and religious values are the needs of every human being. He is very open to everyone, and to all religions. The spirit that is in it is the recognition of human existence depending on the goodness of the Divine. Everything in this world is His creation, and humans can only live happily because of His protection and goodness. In the context of state life, the value of wisdom in Dalihan Natolu can be developed in line with the values of Pancasila, the principles of fair and civilized humanity, and social justice for all Indonesian people. Dalihan Natolu can only be meaningful and useful for humans if the three constituent elements can create harmonious, harmonious and equal relationships and social justice.

Existence Dalihan Natoluwill continue to exist as long as the marriage between humans exists, and it is of universal value because marriage is not limited to fellow Toba Batak people. Unfortunately, the awareness of the shift and obscurity of the meaning of Dalihan Natolu has not been so strong in the Toba Batak community that many young millennials do not understand. This can be seen from the lack of massive discourse movements as a collective learning to explore the values and meanings of the wisdom contained therein. This shift is a result of the onslaught of globalization and modernization.

Finally philosophy Dalihan Natolu wants to emphasize that man is a relational entity. The point is that humans are creatures that cannot possibly not have a relationship with the world of their life. So relationality for humans is a necessity. Relationality is an inevitable reality. Only by establishing a harmonious relationship with Debata Mulajadi Nabolon, Hulahula, Dongan sabutuha, Boru and Friends, can humans have a happy life in this world. In daily life, in general the Toba Batak people have a high commitment to the cultural values of the dalih na tolu culture. This we can see how they consistently adhere to the cultural values inherited by their ancestors, as revealed in the following quotes "omputta na di jolo martungkot siala gundi, adat na pinukka ni parjolo ingkon ihuthonon ni parpudi ". The advice expressed in these quotes has a profound meaning, namely that all the rules set by the ancestors must be obeyed and obeyed and carried out from generation to generation.

Toba Batak society in a cultural system diversion na toluRequired to behave helping or caring for relatives at every opportunity and this behavior for the Toba Batak people is perceived as a high value and is also a noble and noble act. They also think that this culture has deep sacred values build social relationships for life. This is revealed in the traditional advice they got from their ancestors as follows "martagan sipiliton, maransimun so Bolaon, adat ama dohot ompu tokka siuban". The value contained in this customary advice implies the existence of an obedience and obedience to the ancestors that the customs that have been inherited by the true ancestors cannot be changed.

\section{Conclusion}

Local wisdom is a rule of culture that is wise and wise and has noble values that are applied by the community in their lives. In the Batak tribe, local wisdom is known as Dalihan $\mathrm{Na}$ Tolu which binds and has the concept of being tied to the kinship system in society. Loving each other and helping to help is the key to this philosophy and of course very beneficial for our society today. 


\section{References}

Abubakar, Mustafa. (2010). "Membangun Semangat Nasionalisme dengan Bingkai Kearifan Lokal Rakyat Aceh Tinjauan Ketahanan Pangan”, Vol.12, 172-180.

Anecetus B. Sinaga. (1981). The Toba Batak High God. St. Augustin

Armawy, Armaidy. (2008). "Kearifan Lokal Batak Toba Dalihan Na Tolu Dan Good Governance Dalam Birokrasi Publik".Vol. 18

Cecep, Raden, dkk. (2011). 'Kearifan Lokal Tentang Mitigasi Bencana Pada Masyarakat Baduy". Jurnal Makara, Sosial Humaniora, Vol. 15, 68

Frince, S. M., Tambunan, M.A. (2020). The Development of Teaching Materials Based on Local Assistance in the Appreciation Materials of Indonesian Education Students UHKBPNP. Budapest International Research and Critics in Linguistics and Education (BirLE) Journal Vol 3 (4): 1719-1725.

Gultom Rajamarpodang. (1992). "Dalihan Na Tolu Nilai Budaya Suku Batak". Medan: Armanda

Harahap, H Basyral, Siahaan Hotman M. (1987). "Orientasi NilaiNilai Budaya Batak”, Sanggar Willem Iskandar, Jakarta.

Ibrahim Gultom. (2010).“Agama Malim di Tanah Batak”, Jakarta: Bumi Aksara.

Lumban Tobing, Philip. (1956). The Structure of the Toba-Batak Belief in the High God. Amsterdam: Jacob van Campen.

PH.O. Lumban Tobing. (1963). The Structure of the Toba-Batak Belief in the High God. Amsterdam: Jacob Van Campen

Rajamarpodang Gultom. (1992). Dalihan Na Tolu: Nilai Budaya Batak. Medan: Armanda

Sartini. (2004). Menggali Kearifan Lokal Nusantara: Sebuah Kajian Filsafat. Jurnal Filsafat, Vol.37, 111-120

Sihombing, Adrian Adison. (2018). "Mengenal Budaya Batak Toba Melalui Falsafah Dalihan $\mathrm{Na}$ Tolu (Perspektif Kohesi dan Kerukunan)". Jurnal Lektur Keagamaan. Vol. 16, No.2.hal. 356

Sihombing, T.M. (1997). Filsafat Batak: Tentang Kebiasaan-kebiasaan Adat Istiadat. Jakarta: Balai Pustaka.

Simanjuntak, Bungaran Antonius (Penyunting), 2015. Karakter Batak Masa Lalu, Kini, dan Masa Depan, Jakarta: Yayasan Pustaka Obor Indonesia.

Sinaga, Anicetus B. (1991). "Mula, Lapatan, Partording ni Gondang Batak". Sibolga: Keuskupan Sibolga, 1991.

Sri Meiyenti, dalam Robin Fox. (2012). "Perubahan Istilah Kekerabatan Dan Hubungannya Dengan Sistem Kekerabatan Pada Masyarakat Minangkabau”, Jurnal Antropologi, FISIF Universitas Andalas

T.M. Sihombing. (2000). "Filsafat Batak, tentang Kebiasaan-kebiasaan Adat Istiadat", Jakarta: Balai Pustaka.

Togar Nainggolan. (2012). "Batak Toba. Sejarah dan Transformasi Religi”, Medan: Bina Media Perintis.

Zulkarnain, A.Ag., \& Febriamansyah, R. (2008). "Kearifan Lokal dan Pemanfaatan dan Pelestarian Sumberdaya Pesisir”. Jurnal Agribisnis Kerakyatan, Vol.1, 69-85. 